\title{
1 Atmospheric pollutants in peri-urban forests of Quercus ilex: evidence 2 of pollution abatement and threats for vegetation.
}

3 Héctor García-Gomez ${ }^{1}$, Laura Aguillaume ${ }^{2}$, Sheila Izquieta-Rojano ${ }^{4}$, Fernando Valiño $^{1}$, Anna Àvila ${ }^{3}$, 4 David Elustondo ${ }^{4}$, Jesús M. Santamaría ${ }^{4}$, AndrésAlastuey ${ }^{5}$, Héctor Calvete-Sogo ${ }^{1}$, Ignacio González$5 \quad$ Fernández $^{1}$, Rocío Alonso ${ }^{1}$

$6 \quad{ }^{1}$ Ecotoxicology of Air Pollution, CIEMAT, Av. Complutense 40, Ed.70, 28040 Madrid, Spain.

$7 \quad{ }^{2}$ CREAF, Campus de Bellaterra (UAB), Edifici C, 08193Cerdanyola del Vallès, Spain.

$8{ }^{3}$ Universitat Autònoma de Barcelona (UAB), Campus de Bellaterra, 08193 Cerdanyola del Vallès, Spain.

$9 \quad{ }^{4}$ LICA, Universidad de Navarra, C. Irunlarrea 1, 31009 Pamplona, Spain.

$10{ }^{5}$ Institute of Environmental Assessment and Water Research (IDAEA-CSIC), C. Jordi Girona 18-26, 08034

11 Barcelona, Spain.

\section{Keywords}

Atmospheric pollution;nitrogen; ozone; aerosols; ecosystem services; Mediterranean vegetation.

\begin{abstract}
Peri-urban vegetation is generally accepted as a significant remover of atmospheric pollutants, but it could also be threatened by these compounds, with origin in both urban and non-urban areas. To characterize the seasonal and geographical variation of pollutant concentrations and to improve the empirical understanding of the influence of Mediterranean broadleaf evergreen forests on air quality, four forests of Quercus ilex (three peri-urban and one remote) were monitored in different areas in Spain. Concentrations of nitrogen dioxide $\left(\mathrm{NO}_{2}\right)$, ammonia $\left(\mathrm{NH}_{3}\right)$, nitric acid $\left(\mathrm{HNO}_{3}\right)$ and ozone $\left(\mathrm{O}_{3}\right)$ were measured during two years in open areas and inside the forests and aerosols $\left(\mathrm{PM}_{10}\right)$ were monitored in open areas during one year. Ozone was the only air pollutant expected to have direct phytotoxic effects on vegetation according to current thresholds for the protection of vegetation. The concentrations of $\mathrm{N}$ compounds were not high enough to directly affect vegetation but could be contributing through atmospheric $\mathrm{N}$ deposition to the eutrophization of these ecosystems. Peri-urban forests of Quercus ilex showed a significant below-canopy reduction of gaseous concentrations (particularly $\mathrm{NH}_{3}$, with a mean reduction of 29-38\%), which indicated the feasibility of these forests to provide an ecosystem service of air quality improvement. Well-designed monitoring programs are needed to further investigate air quality improvement by peri-urban ecosystems while assessing the threat that air pollution can pose to vegetation.
\end{abstract}

\section{Acknowledgements}

This research was funded by the Spanish project EDEN (CGL2009-13188-C03-02), by the project from Autonomous Government of Madrid AGRISOST-CM (P2013/ABI-2717), and by the European Projects ECLAIRE (FP7-ENV-2011/282910) and Life RESPIRA (LIFE13 ENV/ES/000417). This study was also supported by the Ministry of Agriculture, Food and Environment (Resolución 15398, BOE $n^{\circ}$ 230). The authors would like to acknowledge the Department of Environment (DGQA) of the Autonomous Government of Catalonia for performing the active monitoring of air pollutants at LC ("MSY" station from GAW/ACTRIS monitoring networks). 


\section{Introduction}

2 The continuous growth of urban population has turned air quality into one of the main 3 environmental concerns worldwide. Current urban development needs to consider designs and 4 strategies that minimize atmospheric pollution to improve well-being and human health. In the 5 last years, particular attention has been paid to investigate the role of urban and peri-urban 6 vegetation in improving air quality. Vegetation can remove air pollutants via dry deposition, 7 through interception in the canopy surfaces, and via absorption of gases through the stomata. In 8 particular, urban and peri-urban vegetation has been proposed as a method to reduce air pollutants such as ozone, nitrogen oxides and particulate matter (Alonso et al. 2011; Kroeger et al. 2014; Nowak et al. 2014; Sgrigna et al. 2015). On the other hand, air pollution can affect these forests, impairing their capacity to provide ecosystem services.

Peri-urban areas are transition zones between the denser urban core and the rural hinterland, where natural habitats can be exposed to intermediate concentrations of pollutants linked to both urban and rural activities. Among the most common gaseous pollutants, nitrogen oxides $\left(\mathrm{NO}_{2}\right.$, NO) reach peri-urban areas transported from human agglomerations and highways where they are produced as a result of combustion processes. Nitrogen oxides are in turn precursors for the formation of photochemical oxidants such as ozone $\left(\mathrm{O}_{3}\right)$ and nitric acid $\left(\mathrm{HNO}_{3}\right)$. Ozone is one of the most important and pervasive air pollutants currently affecting vegetation (Kroeger et al. 2014). This pollutant is particularly important in the Mediterranean region, where the highest concentrations in Europe are registered (EEA 2013). Ozone levels are usually greater in periurban and rural areas than in busy urban centres, due to its rapid destruction by reacting with the NO emitted in the cities (The Royal Society 2008). Nitric acid is one of the main components of photochemical smog, together with ozone, and with a similar spatial distribution (Bytnerowicz et al. 1999). In contrast, ammonia $\left(\mathrm{NH}_{3}\right)$ is mainly emitted from agricultural and livestock activities in rural areas. Ammonia and nitric acid can quickly react with each other, or with other atmospheric gases, to formsecondary inorganic aerosols (SIA), that can represent an important fraction of the particulate matter (PM) concentration measured at regional background stations (EEA 2013). Although atmospheric N pollutant levels are usually not high enough to directly damage vegetation, atmospheric $\mathrm{N}$ deposition can contribute to both eutrophication and acidification of ecosystems, which is a bigger problem than the direct exposure to these compounds (Dise et al. 2011; EEA 2013). Atmospheric N deposition can be particularly important in peri-urban areas that are receiving contributions of $\mathrm{N}$ compounds from both urban and agricultural activities. In fact, Mediterranean forests and mountain scrublands close to Barcelona and Madrid cities have been reported to be threatened by N deposition (García-Gómez et al. 2014). 
1 Air pollutant gases and particles are removed from the atmosphere through both wet and dry 2 deposition. In Mediterranean environments, atmospheric deposition can be dominated by dry 3 deposition, which can represent up to $50-95 \%$ of the total deposition in Mediterranean forests 4 (Bytnerowicz and Fenn 1996). In this sense, urban and peri-urban vegetation, through increasing 5 dry deposition, can represent a good strategy to improve air quality, particularly in this region. 6 Dry deposition to vegetation is a function of multiple factors, such as air concentration, chemical 7 properties of the depositing species, atmospheric turbulence, moisture and reactivity of receptor surfaces, and vegetation structure and activity (Fowler et al. 2009).

Measuring pollutant concentrations outside and within peri-urban forests can provide an insight into the role of vegetation in removing air pollutants (Cavanagh et al. 2009; Setälä et al. 2013; Grundström and Pleijel 2014). Although urban vegetation is accepted as an efficient remover of air pollutants, most of the studies are based on large-scale modelling (e.g. Nowak et al. 2014) or laboratory studies (e.g. Chaparro-Suárez et al. 2011), but there are few empirical evidences of the reduction in pollutant concentrations inside urban forested areas (Cavanagh et al. 2009; Grundström and Pleijel 2014). Besides, atmospheric pollution represents a risk for the urban and peri-urban vegetation and should be monitored, particularly in forest potentially withstanding other stressful conditions. Interestingly, $\mathrm{NH}_{3}$ and $\mathrm{HNO}_{3}$ concentrations are scarcely measured in the main air-quality networks, despite being major drivers of atmospheric $\mathrm{N}$ dry deposition to vegetation (Bytnerowicz et al. 2010).

In order to study tropospheric $\mathrm{O}_{3}$, gaseous $\mathrm{N}$ compounds, and suspended $\mathrm{PM}$ in peri-urban forests in Spain, three peri-urban forests of holm oak (Quercus ilex L.) were selected near to three cities in Spain with increasing population and with different influences of traffic and agricultural pollution sources (based on their distances to highways, percentage of agricultural land use and presence of livestock). Another holm oak forest site, far from anthropogenic emissions of air pollutants, was established for comparison. Holm oak is an evergreen broadleaf tree species representative of the Mediterranean Basin and it is present over a wide range of environments in the region, from cold semi-arid to temperate humid bioclimates. This study was enclosed in the EDEN project (Effects of nitrogen deposition in Mediterranean evergreen holm oak forests), whose main goal was to determine and characterize the nitrogen inputs to holm oak forests in the Iberian Peninsula and the effects in the nitrogen biogeochemical cycle. In the present study, air quality measurements from EDEN project are presented and discussed, with the following objectives: 1) to analyse the main air pollutants that could be affecting holm oak forests close to cities, 2) to characterize air pollutant temporal and geographical variation, and 3) to compare air pollutant concentrations outside and inside the forest to improve the empirical understanding of the influence of vegetation on air quality. 


\section{Material and methods}

\subsection{Study sites}

Three holm-oak (Quercus ilex) forests were selected in the vicinity of three cities in Spain with increasing population (Fig. 1, Table 1). The Can Balasc (CB) site is placed in a forest located in a natural protected area $4 \mathrm{~km}$ away from Barcelona with acidic soils and Mediterranean sub-humid climate. The Tres Cantos site (TC) is a forest located in a natural protected area at $9 \mathrm{~km}$ from Madrid, growing on acidic sandy soil with Mediterranean semi-arid climate. The Carrascal site (CA) is located in an agricultural area close to Pamplona $(15 \mathrm{~km})$, with calcareous soil and Mediterranean humid climate, and it is the most agricultural-influenced among the three periurban forests. The canopy in all the sites is dominated by Quercus ilex,mixed with $Q$. humilisin $\mathrm{CB}$. In the case of TC, vegetation was historically managed as a traditional dehesa (a savannahlike agrosilvopastoral system) of $Q$. ilex, but the low management intensity during the last decades has allowed vegetation to grow as a moderately open forest. An additional holm oak forest was selected as a non-urban reference in La Castanya (LC), a long-term biogeochemical study site in a protected mountainous area (Parc Natural del Montseny), situated $40 \mathrm{~km}$ away from Barcelona (Fig. 1) and is included in the GAW/ACTRIS monitoring networks ("MSY" station). This site presents moderately acidic soils and montane Mediterranean climate and it is relatively sheltered from the surrounding lowland sources of atmospheric pollutants (Hereter and Sánchez 1999). The description of the sites was complemented with land use cover and livestock density data obtained from the Corine Land Cover 2006 of the European Environment Agency (http://www.eea.europa.eu/data-and-maps/data/corine-land-cover-2006-raster-3) and from the Spanish National Statistic Institute (http://www.ine.es) respectively (Table 1). ArcGIS software (version 9.2; Environmental Systems Research Institute Inc., Redlands, CA, USA) was employed to summarize these data using a buffer of $25 \mathrm{~km}$ radius around the sampling sites. Meteorological variables were monitored in $\mathrm{CB}, \mathrm{TC}$ and $\mathrm{LC}$ sites, and data from the closest meteorological station were collected for the CA site.

\subsection{Air pollution monitoring}

Atmospheric concentrations of ozone $\left(\mathrm{O}_{3}\right)$, ammonia $\left(\mathrm{NH}_{3}\right)$, nitrogen dioxide $\left(\mathrm{NO}_{2}\right)$ and nitric acid vapour $\left(\mathrm{HNO}_{3}\right)$ were monitored during two years using passive samplers. In every location, two plots were installed: an open-field plot $(\mathrm{O})$ and a below-canopy plot ( $\mathrm{F}$-forest plot). Open and below-canopy plots were selected in order to maintain the same orientation, exposure and elevation.Two replicate samplers per gaseous species were exposed at $2 \mathrm{~m}$ height in each plot. Gases were measured during two-week-long periods between February 2011 and February 2013; except $\mathrm{O}_{3}$ in $\mathrm{CA}$, where the sampling survey was only extended until April 2012. Exceptionally, some sampling periods ( $3 \%$ of the total monitoring time) lasted approximately four weeks. In 
these cases, the same result has been used for the two corresponding regular sampling periods.. During every exposure period, unexposed samplers were used as blanks for each site and type of passive sampler. After collection, all samples were kept refrigerated $\left(4^{\circ} \mathrm{C}\right)$ in darkness until they were analysed in the laboratory.

Tube-type samplers (Radiello ${ }^{\circledR}$ ) were used to measure atmospheric concentrations of $\mathrm{NH}_{3}, \mathrm{NO}_{2}$ and $\mathrm{O}_{3}$. Laboratory analyses were performed according to Radiello's specifications (Fondazione Salvatore Maugeri, 2006). Atmospheric concentrations of $\mathrm{HNO}_{3}$ were measured by means of badge-type samplers manufactured following Bytnerowicz et al. (2005). In CA, Passam® passive samplers and methods were employed during the second year for monitoring $\mathrm{NO}_{2}$ after checking their comparability with Radiello®. For these sampling periods, correction proposed by Plaisance (2011) was applied to avoid biases caused by high wind speeds. The variability of the duplicate passive samplers for each air pollutant averaged from $7 \%$ for $\mathrm{O}_{3}$ to $28 \%$ for $\mathrm{HNO}_{3}$.

Additionally, concentration of $\mathrm{O}_{3}$ and nitrogen oxides ( $\mathrm{NO}$ and $\mathrm{NO}_{2}$ ) were continuously monitored in open-field locations in LC and TC sites with active monitors (in LC: MCV ${ }^{\circledR} 48 \mathrm{AV}$ and Thermo Scientific ${ }^{\circledR} 42 \mathrm{i}-\mathrm{TL}$, respectively; in TC:ML ${ }^{\circledR}$ 9810B and $\mathrm{ML}^{\circledR}$ 9841, respectively). Simultaneous measurements with passive samplers and active monitors were used to estimate mean experimental sampling rates, which were applied to calculate atmospheric concentrations. The experimental sampling rates obtained in LC were employed in CB and CA calculations as well, after checking the similarity with concentrations registered at the closest air quality monitoring stations.

Using the data from the active monitors, accumulated $\mathrm{O}_{3}$ exposure was calculated as AOT40, which is the accumulated amount of hourly $\mathrm{O}_{3}$ concentrations over the threshold value of $40 \mathrm{nl} \mathrm{l}^{-1}$. Following the Ambient Air Quality Directive 2008/50/EC, AOT40 was calculated for the period May-July with the hourly mean values from 8 to 20 hours. Additionally, following the recommendations from the Convention on Long-range Transboundary Air Pollution (CLRTAP 2011), AOT40 was calculated for the entire year (the growing season for $Q$. ilex) during daylight hours.

\subsection{Particulate matter sampling}

Particulate matter with diameter up to $10 \mu \mathrm{m}\left(\mathrm{PM}_{10}\right)$ was collected with $150 \mathrm{~mm}$ quartz microfibre filters (2500 QAO-UP, Pall Life Sciences) using high volume samplers installed in openfield plots of TC, CA and LC sites (Digitel ${ }^{\circledR}$ DH80 in LC -MSY monitoring station; MCV ${ }^{\circledR}$ CAV$\mathrm{A} / \mathrm{mb}$ in TC and CA). Samples were collected from February 2012 to February 2013 once a week,using a flow of $30 \mathrm{~m}^{3} \mathrm{~h}^{-1}$ during 24-h periods. The day of the week for $\mathrm{PM}_{10}$ collection changed weekly. The concentration was gravimetrically determined and main secondary inorganic aerosols $\left(\mathrm{SO}_{4}{ }^{2-}, \mathrm{NO}_{3}^{-}\right.$and $\left.\mathrm{NH}_{4}{ }^{+}\right)$were water-extracted and analysed by ion 
chromatography. For statistical comparison purposes with gaseous pollutant concentrations, $\mathrm{PM}_{10}$ data were grouped and averaged in accordance to passive sampling periods (except for the comparison of the natural dust events with the rest of the samples).

\subsection{Statistical analysis}

Non-parametric statistics was selected for this study because most of the variables did not show a normal distribution according to Shapiro-Wilk test and normal probability plots. Differences among seasons or sites were analysed using the Kruskal-Wallis test; when significant differences were found, differences between pairs of sites were assessed with the Mann-Whitney U test. Correlation between variables was tested with the Spearman rank order correlation coefficient. Differences in pollutant concentration between $\mathrm{O}$ and $\mathrm{F}$ plots were analysed by applying the Wilcoxon matched pair test to the entire sampling period. The temporal variability is described in this study by the coefficient of variation $(\mathrm{CV}=$ standard deviation / mean) of the two-week concentrations for the entire study period. The variability of the duplicate passive samplers for each air pollutant is also described by their respective CV. In this work, seasons were considered as periods of three consecutive months, beginning on $1^{\text {st }}$ January. Statistica software (version 12; StatSoft, Tulsa, OK) was used for statistical analysis. Alfa level was set at 0.05 .

\section{Results}

\subsection{Temporal and spatial patterns of gaseous pollutants}

Seasonal and annual pollutant concentrations and differences among sites are described below based on concentrations in the O plots (Fig. 2; Table 2).

The annual mean of atmospheric $\mathrm{NO}_{2}$ concentration ranged from $4.3 \mu \mathrm{g} \mathrm{m}^{-3}$ in $\mathrm{LC}$ to $16.2 \mu \mathrm{g} \mathrm{m}^{-3}$ in CB (Table 2). The highest two-week concentration reached 39.3 and $37.1 \mu \mathrm{g} \mathrm{m}^{-3}$ registered in CB and TC respectively during the winter 2012 (Supplement, S1). On average for the four sites, temporal variability of $\mathrm{NO}_{2}$ concentration was $53 \%$. Levels of $\mathrm{NO}_{2}$ tended to peak during the coldest seasons (autumn and winter). Significant seasonal differences were detected in the sites closest to the big cities of Barcelona and Madrid (CB and TC). LC experienced the lowest concentrations and the lowest inter-seasonal variability (Fig. 2).

Atmospheric $\mathrm{NH}_{3}$ concentration (Table 2) was the highest in CA $\left(2.5 \mu \mathrm{g} \mathrm{m}^{-3}\right)$ and the lowest in TC and LC $\left(0.7 \mu \mathrm{g} \mathrm{m}^{-3}\right)$. The maximum two-week value $\left(5.3 \mu \mathrm{g} \mathrm{m}^{-3}\right)$ was recorded in CA during late winter (Supplement, S2). The temporal variability showed a mean of 55\% across sites. A consistent seasonal pattern was found in $\mathrm{TC}$, where $\mathrm{NH}_{3}$ concentration increased during spring and summer and decreased during autumn and winter (Fig. 2; Supplement, S2). LC showed a similar seasonal pattern but differences were not statistically significant $(p=0.06)$. On the contrary, in $\mathrm{CB}$ and $\mathrm{CA}$, the highest seasonal concentrations occurred in winter. 
The concentration of $\mathrm{HNO}_{3}$ tended to be higher in the sites closest to the Mediterranean coast

2 ( $\mathrm{CB}$ and $\mathrm{LC}$ ), but differences among sites were not statistically significant (Table 2). The maximum two-week concentrations found in CB and LC (14.5 and $13.9 \mu \mathrm{g} \mathrm{m}^{-3}$ in summer of 2012, respectively) were twice the maximum values found in TC and CA (Supplement, S3). The temporal variability in $\mathrm{HNO}_{3}$ concentration was higher than the variability found for the other air pollutants, with an average value of $110 \%$. A general seasonal pattern was detected in $\mathrm{HNO}_{3}$ concentrations, with higher values during spring and summer and lower values in autumn and winter (Fig. 2).

The annual mean of atmospheric $\mathrm{O}_{3}$ concentrations (Table 2) were significantly lower in the sites closest to the big cities of Barcelona and Madrid (57.0 $\mu \mathrm{g} \mathrm{m}^{-3}$ in $\mathrm{CB}$ and $69.1 \mu \mathrm{g} \mathrm{m}^{-3}$ in TC) than in the more rural ones ( $77.4 \mu \mathrm{g} \mathrm{m}^{-3}$ and $78.2 \mu \mathrm{g} \mathrm{m}^{-3}$ in CA and LC, respectively). Ozone was the air pollutant showing the smallest temporal variability with a mean value of $32 \%$. All sites showed similar seasonal patterns with higher $\mathrm{O}_{3}$ concentration during spring and summer than in autumn and winter (Fig. 2). Ozone exposure accumulated during May-July expressed as AOT40 ranged from $3.9 \mathrm{ppm} \mathrm{h}$ in CA in 2011 to $28.3 \mathrm{ppm} \mathrm{h}$ in TC in 2012 (Table 3). When accumulating $\mathrm{O}_{3}$ exposure throughout the growing season, AOT40 values ranged from $8.2 \mathrm{ppm} \mathrm{h}$ in CA in 2011 to $49.6 \mathrm{ppm} \mathrm{h}$ in TC in 2012 (Table 3).

\subsection{Temporal and spatial patterns of particulate matter}

The concentration of $\mathrm{PM}_{10}$ was higher in CA and TC than in LC (Table 2), although differences were only significant between CA and LC, which showed the lowest annual concentration (18.0 $\mu \mathrm{g} \mathrm{m}^{-3}$ ). Temporal variability in $\mathrm{PM}_{10}$ concentrations was $50 \%$ on average for the three sites. Significant seasonal variations were found in $\mathrm{TC}$ and $\mathrm{LC}$, with the highest $\mathrm{PM}_{10}$ concentrations registered in summer and the lowest in autumn (Fig. 3A). Saharan dust events represented $10 \%$ of the total amount of samples, and occurred more frequently during the summer season. In the three sites, the highest $24 \mathrm{~h}$-concentrations of $\mathrm{PM}_{10}$ (up to $126.4 \mu \mathrm{g} \mathrm{m}^{-3}$ ) were collected during these natural dust events, generally doubling the levels found in the rest of the samples (Fig. 3B).

Regarding SIA composition, no differences among sites were found in particulate ammonium $\left(\mathrm{NH}_{4}{ }^{+}\right)$, while particulate nitrate $\left(\mathrm{NO}_{3}{ }^{-}\right)$was significantly the highest in CA (Table 2). Apparently, Saharan dust intrusions did not affect the $\mathrm{NH}_{4}{ }^{+}$and $\mathrm{NO}_{3}{ }^{-}$concentration in $\mathrm{PM}_{10}$ (data not shown). The atmospheric concentration of both water-soluble nitrogen aerosols showed a marked seasonality, with higher values detected in winter than in the rest of seasons (Figs. 3C and 3D). However, only for $\mathrm{NO}_{3}{ }^{-}$in $\mathrm{CA}$ and $\mathrm{LC}$, these differences were statistically significant. Gaseous nitrogen forms generally predominated over the particulate forms, particularly in spring and summer (Figs. 3E and 3F). However, $\mathrm{NO}_{3}{ }^{-}$clearly predominated over $\mathrm{HNO}_{3}$ during winter in $\mathrm{TC}$ and $\mathrm{CA}$ and during autumn in $\mathrm{LC}$, and $\mathrm{NH}_{4}{ }^{+}$predominated over $\mathrm{NH}_{3}$ during winter in TC. 
1 Additionally, no seasonal variations were recorded in ammonium gas/particle ratio in CA (Fig. $23 \mathrm{~F})$.

3

4

5

\subsection{Differences in gaseous pollutant concentrations between open-field and below-canopy plots}

Below-canopy concentrations of gaseous pollutants were, in general, smaller than levels found in the open-field plots (Fig. 4). These differences were more remarkable for $\mathrm{NH}_{3}$, which showed an annual mean concentration in $\mathrm{F}$ plots $40 \%$ lower than in the O plots in average for the four sites (56\% in LC, and $29-38 \%$ in the peri-urban forests). In the case of $\mathrm{NO}_{2}$, differences were not significant in $\mathrm{CB}$, while the concentrations were significantly lower in the $\mathrm{F}$ plots in the rest of sites ( $41 \%$ in CA, $13 \%$ in TC and $6 \%$ in $\mathrm{LC}$ ). For $\mathrm{HNO}_{3}$, the reduction detected inside the forest was significant in TC and CA, showing average concentrations 11-13\% lower in the F plot compared to the O plot. Ozone concentrations were significantly lower inside the forests in TC and LC (annual mean difference of 7\% and 5\%, respectively).

The reduction of air pollutant concentrations inside the forest showed few evident seasonal patterns. Nitrogen dioxide experienced the highest decrease in concentrations below-canopy (Supplement, S1) during autumn and winter in TC and CA (none and 34\% on average for both seasons, respectively), while in LC this difference was larger in spring (18\%). The differences in $\mathrm{NH}_{3}$ levels were consistent most of the time ( $31 \%$ on average; Supplement, S2), although smaller during the summer in the three peri-urban forests. Regarding $\mathrm{HNO}_{3}$ (Supplement, S3), differences between forest and open plots were slightly higher during spring and autumn in TC and CA (24\% in both sites, averaged for both seasons). The reduction of $\mathrm{O}_{3}$ concentrations inside the forest resulted slightly larger during summer and autumn (8\% in TC and 7\% in LC, averaged for both seasons; Supplement, S4).

\subsection{Correlation analysis of pollutant concentrations and meteorology}

Atmospheric concentrations of $\mathrm{NO}_{2}$ were poorly correlated with meteorological variables, with the exception of TC site, where $\mathrm{NO}_{2}$ levels were negatively correlated to temperature, daily solar radiation and wind speed, and positively correlated to relative humidity. In the rest of sites, $\mathrm{NO}_{2}$ concentrations were negatively correlated with precipitation in $\mathrm{CB}$ and LC, and with wind speed in CA (Table 4). In the case of $\mathrm{NH}_{3}$ concentrations, no correlation was found in CA. In the other sites, relative humidity was negatively correlated to $\mathrm{NH}_{3}$ concentration, while temperature and daily solar radiation were positively correlated in TC and LC, and negatively in CB. Concentrations of $\mathrm{HNO}_{3}$ and $\mathrm{O}_{3}$ were positively correlated with temperature and daily solar radiation, and negatively with relative humidity in all sites. Besides, $\mathrm{HNO}_{3}$ and $\mathrm{O}_{3}$ concentrations 
showed a positive correlation with wind speed in TC and CA, and a negative correlation with precipitation in TC (Table 4).

The concentrations of $\mathrm{PM}_{10}$ were negatively correlated with precipitation in $\mathrm{TC}$ and $\mathrm{CA}$ and positively with solar radiation and temperature in TC and LC. In TC, $\mathrm{PM}_{10}$ was also negatively correlated with humidity. Besides, $\mathrm{PM}_{10}$ was negatively correlated with wind speed in LC. Particulate nitrate was negatively related to temperature and solar radiation only in CA. $\mathrm{NH}_{4}{ }^{+}$ concentrations did not show important correlations with meteorological variables. Particulate $\mathrm{SO}_{4}{ }^{2-}$ was positively correlated to temperature and solar radiation and negatively with wind speed only in LC (Table 4).

No significant correlations among gaseous pollutant were found in CA. In the other sites, $\mathrm{O}_{3}$ and $\mathrm{HNO}_{3}$ concentrations were positively correlated (Table 4). In TC, $\mathrm{O}_{3}$ was also negatively correlated to $\mathrm{NO}_{2}$ and $\mathrm{NH}_{3}$ was positively correlated to $\mathrm{O}_{3}$ and $\mathrm{HNO}_{3}$. Particulate $\mathrm{NH}_{4}{ }^{+}$ concentration was correlated with particulate $\mathrm{NO}_{3}{ }^{-}$in the three sites, and with $\mathrm{SO}_{4}{ }^{2-}$ in $\mathrm{CA}$ and LC. However, $\mathrm{NH}_{4}{ }^{+}$was not correlated with $\mathrm{NH}_{3}$ in any of the sites. Particulate nitrate was positively related to $\mathrm{NO}_{2}$ in $\mathrm{TC}$ and $\mathrm{CA}$, and negatively correlated with $\mathrm{HNO}_{3}$ only in CA (Table 4). Ammonia and $\mathrm{HNO}_{3}$ concentrations were positively correlated to $\mathrm{PM}_{10}$ in TC and LC. Finally, scarce significant correlations with meteorological variables were found for the below-canopy reductions of atmospheric pollutant concentrations (data not shown).

\section{Discussion}

\subsection{Air pollution affecting peri-urban forests}

The annual mean of atmospheric $\mathrm{NO}_{2}$ concentrations decreased from $\mathrm{CB}$ to $\mathrm{LC}$ (from 16.2 to 4.3 $\mu \mathrm{g} \mathrm{m}^{-3}$ ), indicating an order of influence of urban and traffic emissions (CB $>$ TC $\geq \mathrm{CA}>\mathrm{LC}$ ). The levels of $\mathrm{NO}_{2}$ in the three peri-urban forests (CB, TC and CA) were in the range of values recorded in suburban background monitoring stations in 2012 (AirBase v8 dataset; EEA 2014). Therefore, suburban stations might be considered representative of $\mathrm{NO}_{2}$ concentration registered in peri-urban forests. Concentrations of $\mathrm{NO}_{2}$ in the three peri-urban forests followed the expected seasonal pattern of monitoring stations influenced by urban emissions, with highest values recorded during autumn and winter. This seasonal pattern is associated with increasing emissions due to urban combustion for heating purposes and with the lower photochemical intensity during the cold season (Karanasiou et al. 2014). The decrease of $\mathrm{NO}_{2}$ with wind speed in TC and CA pointed to a higher influence of local sources rather than regional contribution. Similar results have been reported in other Mediterranean urban sites (Karanasiou et al. 2014). An analogous response would be expected at $\mathrm{CB}$, but the higher urban density around the site and the lower wind speed (annual mean of $0.8 \mathrm{~m} \mathrm{~s}^{-1}$ ) could be impairing pollutant dispersion. The forest site in 
1 LC was more representative of background $\mathrm{NO}_{2}$ concentrations, since the annual mean was close

2 to the average value of 3.7-3.5 $\mu \mathrm{g} \mathrm{m}^{-3}$ recorded in background stations in Spain in 2011 and 2012

3 respectively (MAGRAMA 2014). Moreover, $\mathrm{NO}_{2}$ concentrations in LC did not show clear

4 seasonal variations, demonstrating the lack of influence of urban emissions. After adding the

5 estimated NO concentration (from the active monitors), none of the sites are expected to reach the

6 critical level for the protection of vegetation $\left(30 \mu \mathrm{g} \mathrm{m}^{-3}\right.$, as annual mean) established in the

7 European Air Quality Directive.

8 The annual mean of $\mathrm{NH}_{3}$ concentrations in $\mathrm{CB}, \mathrm{TC}$ and $\mathrm{LC}$ were low and similar to the levels 9 recorded in Spanish background stations $\left(0.9 \mu \mathrm{g} \mathrm{m}^{-3}\right.$ in 2012; Hjellbrekke 2014). These values 10 were lower than concentrations measured in urban backgrounds of their respective closest cities $11\left(1.7 \mu \mathrm{g} \mathrm{m}^{-3}\right.$ in Madrid and $7.3 \mu \mathrm{g} \mathrm{m}^{-3}$ in Barcelona; Reche et al. 2014), and far from levels 12 registered in regions with intensive farming or livestock (up to $60 \mu \mathrm{g} \mathrm{m}^{-3}$; Fowler et al. 1998; 13 Pinho et al. 2012). The higher concentrations found in CA (annual mean of $2.5 \mu \mathrm{g} \mathrm{m}^{-3}$ ) probably 14 is related to the presence of livestock in the nearby area. The seasonal pattern of $\mathrm{NH}_{3}$ 15 concentrations in TC and LC, with higher values during spring and summer, could be explained 16 by an increasing volatilisation and emission of $\mathrm{NH}_{3}$ from biological sources under warm 17 conditions. In the case of $\mathrm{CB}$, the highest values recorded in autumn and winter might be related to the emissions of $\mathrm{NH}_{3}$ from an industrial area $6.5 \mathrm{~km}$ west of $\mathrm{CB}$. Concentrations of $\mathrm{NH}_{3}$ at this site were significantly correlated with west winds $(\mathrm{p}<0.01$; data not shown), the most frequent wind in autumn and winter. The winter maxima $\mathrm{NH}_{3}$ levels in $\mathrm{CA}$ were in agreement with the fertilization practices of cereal crops in the region during this season. Since the annual mean of $\mathrm{NH}_{3}$ concentrations did not exceed the $3 \mu \mathrm{g} \mathrm{m}^{-3}$ critical level proposed for the protection of higher plants in any of the sites, these forests are not expected to experience relevant ammonia pollution effects (CLRTAP 2011). Moreover, the critical level of $1 \mu \mathrm{g} \mathrm{m}^{-3}$ for the protection of lichens and bryophytes (Cape et al. 2009; CLRTAP 2011) was only exceeded in CA.

No significant differences in $\mathrm{HNO}_{3}$ annual concentration were detected among the sites included in this study. The concentrations of $\mathrm{HNO}_{3}$ in the three peri-urban forests were in the range of values found in other peri-urban areas in the Mediterranean region (summer values of $2.8-4.2 \mu \mathrm{g}$ $\mathrm{m}^{-3}$; Danalatos and Glavas 1999) and higher than in urban sites (yearly averaged values of $0.8-1.5$ $\mu \mathrm{g} \mathrm{m}{ }^{-3}$; Anatolaki and Tsitouridou 2007; Tzanis et al. 2009). However, even the highest concentrations were below the values reported in forested areas of San Bernardino Mountains in Southern California, where topography, climate and emissions linked tohigh population favour $\mathrm{HNO}_{3}$ formation (Bytnerowicz and Fenn 1996; Jovan et al. 2012). The typical higher $\mathrm{HNO}_{3}$ values recorded during spring and summer in the study sites can be explained by the photochemical origin of this pollutant (Bytnerowicz et al. 2010; Tzanis et al. 2009). In this sense, positive correlations between solar radiation and $\mathrm{HNO}_{3}$ concentration were found for all the sites. 
1 The highest levels were found in LC, which must respond to pollutant-transport mechanisms

2 rather than to an in-situ formation of $\mathrm{HNO}_{3}$, since this is a rural site with low concentration of

$3 \mathrm{NO}_{2}$ (chemical precursor of $\mathrm{HNO}_{3}$ ). In fact, ageing of air masses over the Iberian Peninsula and

4 recirculation along the Mediterranean coast have been reported as processes increasing levels of

5 oxidants, acidic compounds, aerosols and ozone (Escudero et al. 2014; Millán et al. 2002).

6 Although very little information is available on direct effects of $\mathrm{HNO}_{3}$ on vegetation, the

7 concentrations found in this study are much lower than the levels reported for epicuticular damage (Padgett et al. 2009).

The annual mean concentration of $\mathrm{O}_{3}$ increased from $\mathrm{CB}$ to $\mathrm{LC}$, following an opposite order of urban influence to the one found for $\mathrm{NO}_{2}$ concentration. A similar behaviour has been described in other studies around cities in the Mediterranean area (Domínguez-López et al. 2014; Escudero et al. 2014). CB showed an annual mean similar to values found in 2012 in Spanish suburban areas, while the other sites showed values clearly typical of rural areas (means of 59.0and 67.8 $\mu \mathrm{g}$ $\mathrm{m}^{-3}$, respectively; EEA 2014). Ozone concentrations in the peri-urban forests showed the typical seasonal variations with higher levels during spring and summer, responding to the sum of the hemispheric-scale spring maximum, the increased photochemical production and transport processes, as well as the above mentioned ageing of air masses and recirculation (Cristofanelli and Bonasoni 2009; Millán et al. 2002). In fact, ozone concentrations were significantly correlated with temperature and solar radiation. Besides, the emission of biogenic volatile organic compounds (BVOCs) by vegetation is known to be correlated with temperature, and can exacerbate photochemical reactivity, and thus $\mathrm{O}_{3}$ formation (Calfapietra et al. 2013). All the calculated AOT40 values were above the concentration-based $\mathrm{O}_{3}$ critical level proposed by the CLRTAP for protecting forest trees (5 ppm $\mathrm{h}$ for the growing season; CLRTAP 2011). The threshold levels for the protection of vegetation established in the European Directive 2008/50/EC (9 ppm h for the period May-July) were also overreached, with the exception of CB site in 2011. Moreover, experimental values of AOT40 similar to those found in this study have been proved to cause a decrease of growth in seedlings of Q. ilex (Alonso et al. 2014; Gerosa et al. 2015).

In the two peri-urban forests with aerosol measurements (TC and CA), the annual mean concentrations of $\mathrm{PM}_{10}$ were close to the urban background levels measured in Spanish big cities in 2012 (mean of $26 \mu \mathrm{g} \mathrm{m}^{-3}$; MAGRAMA, 2014), and well above the values measured in Spanish background stations (12.9 $\mu \mathrm{g} \mathrm{m}^{-3}$; Hjellbrekke 2014). On the other hand, concentrations of particulate $\mathrm{NO}_{3}{ }^{-}$and $\mathrm{NH}_{4}{ }^{+}$were similar to the national background levels in $\mathrm{TC}\left(1.2 \mu \mathrm{g} \mathrm{NO}_{3}{ }^{-} \mathrm{m}^{-3}\right.$, and $0.4 \mu \mathrm{g} \mathrm{NH}_{4}{ }^{+} \mathrm{m}^{-3}$; Hjellbrekke 2014), but almost double in CA. The increased concentration of $\mathrm{NO}_{3}{ }^{-}$and $\mathrm{NH}_{4}{ }^{+}$in $\mathrm{CA}$ could respond to the elevated $\mathrm{NH}_{3}$ concentration caused by agricultural activities, which, combined with the low temperatures, facilitates the formation and stability of ammonium nitrate $\left(\mathrm{NH}_{4} \mathrm{NO}_{3}\right)$. Moreover, at this site, $\mathrm{NO}_{3}{ }^{-}$and $\mathrm{HNO}_{3}$ showed a negative 
correlation, suggesting the existence of conversion of one into the other. The seasonality in $\mathrm{PM}_{10}$ is in agreement with previous studies that attributed the higher summer concentrations to low precipitation, high resuspension, photochemical oxidation and higher frequency of Saharan dust outbreaks (Escudero et al. 2005; Querol et al. 2008; Rodríguez et al. 2002). Interestingly, the natural events of Saharan dust did not modify $\mathrm{NO}_{3}{ }^{-}$and $\mathrm{NH}_{4}{ }^{+}$concentrations. The seasonality observed on particulate $\mathrm{N}$ compounds was more related with the thermal instability of $\mathrm{NH}_{4} \mathrm{NO}_{3}$, pointing out the importance of temperature-dependent processes within the SIA in the Mediterranean region (Querol et al. 2008; Pey et al. 2009). Gaseous $\mathrm{HNO}_{3}$ and $\mathrm{NH}_{3}$ predominated over particulate forms most of the year but aerosol fraction was important mainly during winter. This seasonal variation in gas/aerosol ratios may have implications for $\mathrm{N}$ dry deposition estimations and, therefore, should be further investigated. Little information is available on direct effects of particles on vegetation and no threshold of aerosol concentration has been defined yet for the protection of vegetation.

According to the established thresholds and the available scientific evidences, the results indicate that $\mathrm{O}_{3}$ is the only air pollutant considered in this work which is expected to have direct phytotoxic effects on vegetation. The concentrations of $\mathrm{N}$ compounds seemed to be not high enough to directly affect vegetation but could be contributing through atmospheric $\mathrm{N}$ deposition to the eutrophization of these ecosystems. Moreover, although evergreen broadleaf Mediterranean woody species are assumed to be tolerant to air pollution due to their sclerophyllic adaptations, recent publications suggest that the addition and interaction of different stress factors $\left(\mathrm{O}_{3}, \mathrm{~N}\right.$ deposition, drought) can be affecting the growth of the trees (Alonso et al. 2014; Gerosa et al. 2015) and accompanying pastures (Calvete-Sogo et al. 2014). Thus, monitoring of nitrogen compounds such as $\mathrm{NH}_{3}$ and $\mathrm{HNO}_{3}$ should be incorporated into air quality monitoring networks.

\subsection{Below-canopy reduction of atmospheric pollutant concentrations}

Air pollutant concentrations measured outside and inside the forest ( $\mathrm{O}$ and $\mathrm{F}$ plots) were compared to analyse the influence of vegetation in air quality. In general, the pollutants considered showed lower concentrations inside the forests. Below-canopy reduction of $\mathrm{NO}_{2}$ concentration in our study sites ranged from none in $\mathrm{CB}$, to $41 \%$ in CA.This high reduction detected in CA could be enhanced by the location of the sampling plots, which were at the same distance, but on the opposite sides of a highway. As a result, the $\mathrm{O}$ and $\mathrm{F}$ plots were located downwind and upwind from the highway, respectively, in relation to predominant winds (Supplement, Figure S5). Statistically significant reductions of $\mathrm{NO}_{2}$ concentrations inside holm oak forests were found in TC and LC, with averaged values of $13 \%$ and $6 \%$, respectively. These reductions are comparable to (Grundström and Pleijel 2014) or higher than (Harris and Manning 2010; Setälä et al. 2013) values reported in similar empirical studies with deciduous forest 
species. The larger differences in $\mathrm{NO}_{2}$ levels in $\mathrm{LC}$ were detected during spring, the time when holm oak forests usually show higher stomatal conductance (Alonso et al. 2008). Other authors have reported that $\mathrm{NO}_{2}$ deposition onto forest canopy is governed by plant stomatal aperture (Chaparro-Suárez et al. 2011; Sparks 2009). This behaviour was not observed in TC and CA, where the highest reductions were found during autumn and winter, suggesting that other atmospheric and biogeochemical interactions could be implicated and need further research. In this sense, the lack of below-canopy reduction in $\mathrm{CB}$ could not be explained by meteorological variables or different pollutant exposure. Other authors have suggested that $\mathrm{NO}$ emissions from forest soil in areas with high $\mathrm{O}_{3}$ levels, could result in the formation of $\mathrm{NO}_{2}$ below the canopy (Harris and Manning, 2010; Fowler, 2002), diminishing the difference of $\mathrm{NO}_{2}$ concentrations between outside and inside the canopy. Since dry deposition of atmospheric pollutants depends on multiple factors such as micrometeorology, spatial heterogeneity, plant structure and physiology, and biochemical interaction, further research is needed to clarify the influence of vegetation on air quality.

Below-canopy concentrations of $\mathrm{NH}_{3}$ were on average $40 \%$ lower than in the open field, suggesting that holm oak forests act as sinks of ammonia. This difference was relatively higher in the most natural forest (56\% in LC) than in the peri-urban ones (29-38\%). Since $\mathrm{NH}_{3}$ stomatal fluxes are bi-directional, emission or deposition of $\mathrm{NH}_{3}$ will occur depending on ecosystem $\mathrm{N}$ status, stomatal conductance, and the ratio between atmospheric and canopy $\mathrm{NH}_{3}$ concentration (Behera et al. 2013; Fowler et al. 2009). The below-canopy reductions of $\mathrm{NH}_{3}$ were consistent throughout most of the year, but smaller during the summer, a period of low plant physiological activity in this type of forest. These results indicate a certain regulation of $\mathrm{NH}_{3}$ fluxes by stomatal uptake. However, $\mathrm{NH}_{3}$ canopy retention was not the highest in spring, when plants usually experience maximum stomatal conductance, thus other mechanisms must affect the overall ammonia retention by the canopy in autumn and winter. Among other major drivers of atmospheric $\mathrm{NH}_{3}$ deposition into the canopy, leaf area density, and leaf surface wetness and acidity can enhance the deposition onto the cuticles and epiphytic communities (Geiser et al. 2010; Massad et al. 2010).

The differences in $\mathrm{HNO}_{3}$ concentration between $\mathrm{O}$ and $\mathrm{F}$ plots were only significantly detected in TC and CA, with reductions of 11-13\% on annual average. Among the $\mathrm{N}$ gaseous pollutants, $\mathrm{HNO}_{3}$ is supposed to have the highest surface deposition velocity due to its highly reactive and soluble nature, which should lead to large rates of deposition onto leaf surfaces (Fowler et al. 2009). However, the rates of bellow-canopy $\mathrm{HNO}_{3}$ reduction are similar to those of $\mathrm{NO}_{2}$ in $\mathrm{TC}$ and $\mathrm{LC}$, and lower than those of $\mathrm{NH}_{3}$. No clear seasonal patterns were found in the below-canopy reduction of $\mathrm{HNO}_{3}$ concentrations that could indicate the main processes involved in $\mathrm{HNO}_{3}$ dry 
1 In regards to $\mathrm{O}_{3}$ concentrations, urban and peri-urban vegetation has been proposed as a strategy

2 to absorb $\mathrm{O}_{3}$ and diminish atmospheric concentrations (Alonso et al. 2011; Kroeger et al. 2014).

3 In our study, $\mathrm{O}_{3}$ levels were significantly reduced inside the forests in TC and LC with an average

4 decrease of 5-7\%. The largest below-canopy reduction of $\mathrm{O}_{3}$ concentration occurred in summer

5 and autumn, suggesting that stomatal uptake was not the only process involved in this decline,

6 since stomatal conductance in usually low during the summer in these forests due to drought

7 stress. Actually, non-stomatal $\mathrm{O}_{3}$ deposition in holm oak forests has been reported to account up

8 to ca. $60 \%$ of the total ozone flux (Fares et al. 2014). Surface wetness of the canopy and other

9 forest surfaces can enhance non-stomatal deposition of $\mathrm{O}_{3}$ (Altimir et al. 2006). This process

10 could explain the higher reductions of $\mathrm{O}_{3}$ detected during autumn, the wettest season in all the

11 sites. Besides, increased BVOCs emissions linked to high temperatures during the summer could

12 be favouring the photochemical production of $\mathrm{O}_{3}$ (Calfapietra et al. 2013). This formation of $\mathrm{O}_{3}$

13 should be more apparent in the open-field plots due to their higher insolation,increasing the

14 difference in $\mathrm{O}_{3}$ concentrations between $\mathrm{O}$ and $\mathrm{F}$ plots during this season.

\section{Conclusions}

17 Peri-urban forests are exposed to air pollutants coming from both urban and rural activities.

18 Ozone concentrations around Spanish cities are high enough to directly impact peri-urban 19 vegetation. The concentrations of $\mathrm{N}$ compounds would no directly threat vegetation, but could be contributing, through atmospheric $\mathrm{N}$ deposition, to the eutrophization of these ecosystems. Besides, the interaction of different stress factors $\left(\mathrm{O}_{3}, \mathrm{~N}\right.$ deposition, drought $)$ could be affecting plant growth and ecosystem functioning. On the other hand, peri-urban forests of Quercus ilex have proved to experience a significant below-canopy reduction of pollutant concentrations, particularly of $\mathrm{NH}_{3}$, but also of $\mathrm{NO}_{2}, \mathrm{HNO}_{3}$ and $\mathrm{O}_{3}$. These results provide scientific evidence of the ability of these ecosystems to improve air quality in urban agglomerations, but further research is still needed to quantify the relevance of this ecosystem service. The high variability found in this study across sites and seasons points that processes and environmental factors involved in air pollution removal must be characterized in order to manage these forest for improving air quality. Well-designed monitoring programs of urban and peri-urban forests could accomplish both objectives of further investigate air quality improvement while assessing the threat that air pollution can pose to vegetation. 


\section{References}

Alonso R, Elvira S, González-Fernández I, et al (2014) Drought stress does not protect Quercus ilex L. from ozone effects: Results from a comparative study of two subspecies differing in ozone sensitivity. Plant Biol 16:375-384. doi: 10.1111/plb.12073

Alonso R, Elvira S, Sanz MJ, et al (2008) Sensitivity analysis of a parameterization of the stomatal component of the $\mathrm{DO}_{3} \mathrm{SE}$ model for Quercus ilex to estimate ozone fluxes. Environ Pollut 155:473-480. doi: 10.1016/j.envpol.2008.01.032

Alonso R, Vivanco MG, González-Fernández I, et al (2011) Modelling the influence of periurban trees in the air quality of Madrid region (Spain). Environ Pollut 159:2138-2147. doi: 10.1016/j.envpol.2010.12.005

Altimir N, Kolari P, Tuovinen J-P, et al (2006) Foliage surface ozone deposition: a role for surface moisture? Biogeosciences Discuss 2:1739-1793. doi: 10.5194/bgd-2-1739-2005

Anatolaki C, Tsitouridou R (2007) Atmospheric deposition of nitrogen, sulfur and chloride in Thessaloniki, Greece. Atmos Res 85:413-428. doi: 10.1016/j.atmosres.2007.02.010

Behera SN, Sharma M, Aneja VP, Balasubramanian R (2013) Ammonia in the atmosphere: A review on emission sources, atmospheric chemistry and deposition on terrestrial bodies. Environ SciPollut Res 20:8092-8131. doi: 10.1007/s11356-013-2051-9

Burkhardt J, Kaiser H, Kappen L, Goldbach HE (2001) The possible role of aerosols on stomatal conductivity for water vapour. Basic ApplEcol 2:351-364. doi: 10.1078/1439-1791-00062

Bytnerowicz A, Fenn ME (1996) nitrogen deposition in California forests : A review. Environ Pollut 92:127-146.

Bytnerowicz A, Fraczek W, Schilling S, Alexander D (2010) Spatial and temporal distribution of ambient nitric acid and ammonia in the Athabasca Oil Sands Region, Alberta. J Limnol 69:11-21. doi: 10.3274/JL10-69-S1-03

Bytnerowicz A, Padgett P, Percy K, et al (1999) Direct effects of nitric acid on forest trees. In: Miller PR (ed) Oxidant Air Pollution Impacts in the Montane Forests of Southern California (Ecological Studies 134). Springer, New York, pp 270-287

Bytnerowicz A, Sanz M, Arbaugh M, et al (2005) Passive sampler for monitoring ambient nitric acid (HNO) and nitrous acid (HNO) concentrations. Atmos Environ 39:2655-2660. doi: 10.1016/j.atmosenv.2005.01.018

Calfapietra C, Fares S, Manes F, et al (2013) Role of Biogenic Volatile Organic Compounds (BVOC) emitted by urban trees on ozone concentration in cities: A review. Environ Pollut 183:71-80. doi: 10.1016/j.envpol.2013.03.012 
Calvete-Sogo H, Elvira S, Sanz J, et al (2014) Current ozone levels threaten gross primary production and yield of Mediterranean annual pastures and nitrogen modulates the response. Atmos Environ 95:197-206. doi: 10.1016/j.atmosenv.2014.05.073

Cape JN, van der Eerden LJ, Sheppard LJ, et al (2009) Evidence for changing the critical level for ammonia. Environ Pollut 157:1033-7. doi: 10.1016/j.envpol.2008.09.049

Cavanagh JAE, Zawar-Reza P, Wilson JG (2009) Spatial attenuation of ambient particulate matter air pollution within an urbanised native forest patch. Urban For Urban Green 8:2130.doi: 10.1016/j.ufug.2008.10.002

Chaparro-Suarez IGG, Meixner FXX, Kesselmeier J (2011) Nitrogen dioxide $\left(\mathrm{NO}_{2}\right)$ uptake by vegetation controlled by atmospheric concentrations and plant stomatal aperture. Atmos Environ 45:5742-5750. doi: 10.1016/j.atmosenv.2011.07.021

CLRTAP (2011) Mapping critical levels for vegetation. In: UNECE Convention on Long-range Transboundary Air Pollution (ed) Manual on Methodologies and Criteria for Modelling and Mapping Critical Loads \& Levels and Air Pollution Effects, Risks and Trends. Available at: www.icpmapping.org

Cristofanelli P, Bonasoni P (2009) Background ozone in the southern Europe and Mediterranean area: Influence of the transport processes. Environ Pollut 157:1399-1406. doi: 10.1016/j.envpol.2008.09.017

Danalatos D, Glavas S (1999) Gas phase nitric acid, ammonia and related particulate matter at a Mediterranean coastal site, Patras, Greece.Atmos Environ 33:3417-3425. doi: 10.1016/S1352-2310(98)00342-2

Dise NB, Ashmore M, Belyazid S, et al (2011) Nitrogen as a threat to European terrestrial biodiversity. In: Sutton MA, et al (eds) The European nitrogen assessment. Sources, effects and policy perspectives. Cambridge University Press, pp 463-494

Domínguez-López D, Adame JA, Hernández-Ceballos MA, et al (2014) Spatial and temporal variation of surface ozone, $\mathrm{NO}$ and $\mathrm{NO}_{2}$ at urban, suburban, rural and industrial sites in the southwest of the Iberian Peninsula. Environ Monit Assess 186:5337-5351. doi: 10.1007/s10661-014-3783-9

EEA (2013) Air quality in Europe - 2013 report (EEA Report No 9/2013).

EEA (2014) Airbase v8. Available at: http://www.eea.europa.eu/data-and-maps/data/airbase-theeuropean-air-quality-database-8 (last accessed 15.10.14), European Environmental Agency

Escudero M, Castillo S, Querol X, et al (2005) Wet and dry African dust episodes over eastern Spain.J Geophys Res D Atmos 110:1-15.doi: 10.1029/2004JD004731 
Escudero M, Lozano A, Hierro J, et al (2014) Urban influence on increasing ozone concentrations in a characteristic Mediterranean agglomeration. Atmos Environ 99:322-332. doi: 10.1016/j.atmosenv.2014.09.061

Fares S, Savi F, Muller J, et al (2014) Simultaneous measurements of above and below canopy ozone fluxes help partitioning ozone deposition between its various sinks in a Mediterranean Oak Forest. Agric For Meteorol 198-199:181-191. doi: 10.1016/j.agrformet.2014.08.014

Fondazione Salvatore Maugeri (2006) Instruction manual for Radiello sampler. Edition 01/2006. http://www.radiello.com

Fowler D, Pilegaard K, Sutton MA, et al (2009) Atmospheric composition change: EcosystemsAtmosphere interactions. Atmos Environ 43:5193-5267. doi: 10.1016/j.atmosenv.2009.07.068

Fowler D, Pitcairn CER, Sutton MA, et al (1998) The mass budget of atmospheric ammonia in woodland within $1 \mathrm{~km}$ of livestock buildings. Environ Pollut 102:343-348.

García-Gómez H, Garrido JL, Vivanco MG, et al (2014) Nitrogen deposition in Spain: modeled patterns and threatened habitats within the Natura 2000 network. Sci Total Environ 485486:450-60. doi: 10.1016/j.scitotenv.2014.03.112

Geiser LH, Jovan SE, Glavich D, Porter MK (2010) Lichen-based critical loads for atmospheric nitrogen deposition in Western Oregon and Washington Forests, USA. Environ Pollut 158:2412-2421. doi: 10.1016/j.envpol.2010.04.001

Gerosa G, Fusaro L, Monga R, et al (2015) A flux-based assessment of above and below ground biomass of Holm oak (Quercus ilex L.) seedlings after one season of exposure to high ozone concentrations. Atmos Environ 113:41-49. doi: 10.1016/j.atmosenv.2015.04.066

Gerosa G, Vitale M, Finco A, et al (2005) Ozone uptake by an evergreen Mediterranean Forest (Quercus ilex) in Italy. Part I: Micrometeorological flux measurements and flux partitioning. Atmos Environ 39:3255-3266. doi: 10.1016/j.atmosenv.2005.01.056

Grundström M, Pleijel $\mathrm{H}$ (2014) Limited effect of urban tree vegetation on $\mathrm{NO}_{2}$ and $\mathrm{O}_{3}$ concentrations near a traffic route. Environ Pollut 189:73-6. doi: 10.1016/j.envpol.2014.02.026

Harris TB, Manning WJ (2010) Nitrogen dioxide and ozone levels in urban tree canopies. Environ Pollut 158:2384-6. doi: 10.1016/j.envpol.2010.04.007

Hereter A, Sánchez JR (1999) Experimental Areas of Prades and Montseny. In: Rodà, F., et al. (eds) Ecology of Mediterranean evergreen oak forests. Springer-Verlag Berlin Heidelberg, New York, pp 15-28. 
Hjellbrekke A-G (2014) Data report 2012. Acidifying and eutrophying compounds and particulate matter (EMEP/CCC, 03/2014). Edited by Norwegian Institute for Air Research (NILU) - Chemical Coordination Center of EMEP (CCC), Oslo.

Jovan S, Riddell J, Padgett PE, Nash TH (2012) Eutrophic lichens respond to multiple forms of N: implications for critical levels and critical loads research. EcolAppl 22:1910-22.

Karanasiou A, Querol X, Alastuey A, et al (2014) Particulate matter and gaseous pollutants in the Mediterranean Basin: Results from the MED-PARTICLES project. Sci Total Environ 488489:297-315. doi: 10.1016/j.scitotenv.2014.04.096

Kroeger T, Escobedo FJ, Hernandez JL, et al (2014) Reforestation as a novel compliance measure in State Implementation Plans for ground-level ozone. ProcNatlAcadSci U S A 52:1-43. doi: 10.1073/pnas.1409785111

MAGRAMA (2014) Banco Público de Indicadores Ambientales. Edited by Spanish Ministry of Agriculture, Food and Environment (MAGRAMA). Available at http://www.magrama.gob.es

Massad R-S, Nemitz E, Sutton MA (2010) Review and parameterisation of bi-directional ammonia exchange between vegetation and the atmosphere. AtmosChem Phys 10:1035910386. doi: 10.5194/acp-10-10359-2010

Millán MM, Sanz MJ, Salvador R, Mantilla E (2002) Atmospheric dynamics and ozone cycles related to nitrogen deposition in the western Mediterranean. 118:167-186.

Nowak DJ, Hirabayashi S, Bodine A, Greenfield E (2014) Tree and forest effects on air quality and human health in the United States. Environ Pollut 193:119-129. doi: 10.1016/j.envpol.2014.05.028

Padgett PE, Parry SD, Bytnerowicz A, Heath RL (2009) Image analysis of epicuticular damage to foliage caused by dry deposition of the air pollutant nitric acid. J Environ Monit 11:63-74. doi: $10.1039 / \mathrm{b} 804875 \mathrm{~d}$

Pey J, Perez N, Castillo S, et al (2009) Geochemistry of regional background aerosols in the Western Mediterranean. Atmos Res 94:422-435.

Pinho P, Theobald MR, Dias T, et al (2012) Critical loads of nitrogen deposition and critical levels of atmospheric ammonia for semi-natural Mediterranean evergreen woodlands. Biogeosciences 9:1205-1215. doi: 10.5194/bg-9-1205-2012

Plaisance H (2011) The effect of the wind velocity on the uptake rates of various diffusive samplers. Int J Environ Anal Chem 91:1341-1352. doi: 10.1080/03067311003782625 
Querol X, Alastuey A, Moreno T, et al (2008) Spatial and temporal variations in airborne particulate matter (PM10 and PM2.5) across Spain 1999-2005. Atmos Environ 42:39643979.

Reche C, Viana M, Karanasiou A, et al (2014) Urban $\mathrm{NH}_{3}$ levels and sources in six major Spanish cities. Chemosphere 119C:769-777. doi: 10.1016/j.chemosphere.2014.07.097

Rodríguez S, Querol X, Alastuey A, Mantilla E (2002) Origin of high summer PM10 and TSP concentrations at rural sites in Eastern Spain. Atmos Environ 36:3101-3112. doi: 10.1016/S1352-2310(02)00256-X

Setälä H, Viippola V, Rantalainen A-LL, et al (2013) Does urban vegetation mitigate air pollution in northern conditions? Environ Pollut 183:104-112. doi: 10.1016/j.envpol.2012.11.010

Sgrigna G, Sæbø A, Gawronski S, et al (2015) Particulate Matter deposition on Quercus ilex leaves in an industrial city of central Italy. Environ Pollut 197:187-194. doi: 10.1016/j.envpol.2014.11.030

Sparks JP (2009) Ecological ramifications of the direct foliar uptake of nitrogen.Oecologia 159:1-13. doi: 10.1007/s00442-008-1188-6

The Royal Society (2008) Ground-level ozone in the 21st century: future trends, impacts and policy implications. Edited by: Fowler D, et al. R. Soc., London.

Tzanis C, Varotsos C, Ferm M, et al (2009) Nitric acid and particulate matter measurements at Athens, Greece, in connection with corrosion studies. AtmosChem Phys Discuss 9:1468314711. doi: 10.5194/acpd-9-14683-2009 
1 Table 1.Characterization of the study sites.

\begin{tabular}{|c|c|c|c|c|}
\hline $\begin{array}{l}\text { Site code } \\
\text { Site name }\end{array}$ & $\begin{array}{c}\text { CB } \\
\text { Can Balasc }\end{array}$ & $\begin{array}{c}\text { TC } \\
\text { Tres Cantos }\end{array}$ & $\begin{array}{c}\text { CA } \\
\text { Carrascal }\end{array}$ & $\begin{array}{c}\text { LC } \\
\text { La Castanya }\end{array}$ \\
\hline Province (administrative unit) & Barcelona & Madrid & Navarra & Barcelona \\
\hline Type of site & Peri-urban & Peri-urban & Peri-urban & Rural \\
\hline Altitude (m) & 255 & 705 & 592 & 696 \\
\hline Longitude & $2^{\circ} 04^{\prime} 54^{\prime \prime} \mathrm{E}$ & $3^{\circ} 43^{\prime} 59^{\prime \prime} \mathrm{O}$ & $1^{\circ} 38^{\prime} 40^{\prime \prime} \mathrm{O}$ & $2^{\circ} 21^{\prime} 29^{\prime \prime} \mathrm{E}$ \\
\hline Latitude & $41^{\circ} 25^{\prime} 47^{\prime \prime} \mathrm{N}$ & $40^{\circ} 35^{\prime} 17^{\prime \prime} \mathrm{N}$ & $42^{\circ} 39^{\prime} 13^{\prime \prime} \mathrm{N}$ & $41^{\circ} 46^{\prime} 47^{\prime \prime} \mathrm{N}$ \\
\hline Mean annual temperature $\left({ }^{\circ} \mathrm{C}\right)^{1}$ & 15.2 & 14.6 & 12.3 & 13.7 \\
\hline Mean annual rainfall $\left(\mathrm{mm} \mathrm{y}^{-1}\right)^{1}$ & 652 & 348 & 645 & 812 \\
\hline Distance to the nearest big city $(\mathrm{km})$ & 4 & 9 & 15 & 40 \\
\hline $\begin{array}{l}\text { Population of the nearest big city } \\
\text { (million inhabitants) }\end{array}$ & 1.6 & 3.2 & 0.20 & 1.6 \\
\hline Distance to the nearest highway $(\mathrm{km})$ & 0.15 & 1.5 & 0.05 & 16 \\
\hline $\begin{array}{l}\text { Average daily flow in the nearest } \\
\left.\text { road (thousand vehicles day }{ }^{-1}\right)^{2}\end{array}$ & $40-50$ & $50-60$ & $20-30$ & $20-30$ \\
\hline Agricultural land-use cover ${ }^{3}$ & $23 \%$ & $21 \%$ & $62 \%$ & $23 \%$ \\
\hline Artificial land-use cover ${ }^{3}$ & $35 \%$ & $28 \%$ & $3.1 \%$ & $7.6 \%$ \\
\hline Livestock density $\left(\mathrm{LU} \mathrm{km}^{-2}\right)^{4}$ & 14.5 & 13.7 & 26.9 & 88.8 \\
\hline
\end{tabular}

$2 \quad 1$ : Mean values calculated for the study period.

32 : Values for 2012 from the Spanish Ministry of Development (http://www.fomento.gob.es/).

$4 \quad 3,4$ :From the Corine Land Cover 2006 (http://www.eea.europa.eu/data-and-maps/data/corine-

5 land-cover-2006-raster-3) and the Spanish National Statistic Institute (http://www.ine.es),

6 respectively, using a buffer of $25 \mathrm{~km}$ radius around the sampling sites. 
1 Table 2.Basic statistics of the monitored pollutant concentrations in open-field plots for 2 the entire monitoring periods.

\begin{tabular}{|c|c|c|c|c|}
\hline & SITE & MEAN & MIN. - MAX. & $\mathbf{C V}$ \\
\hline \multirow{4}{*}{$\begin{array}{c}\mathrm{NO}_{2} \\
\left(\mu \mathrm{g} \mathrm{m}^{-3}\right)\end{array}$} & CB & $16.2 \pm 1.0 \mathrm{a}$ & $5.7-39.3$ & $42 \%$ \\
\hline & TC & $11.1 \pm 1.1 \mathrm{~b}$ & $3.8-37.1$ & $71 \%$ \\
\hline & $\mathbf{C A}$ & $10.6 \pm 0.7 b$ & $4.4-26.0$ & $45 \%$ \\
\hline & LC & $4.3 \pm 0.3 \mathrm{c}$ & $0.8-9.4$ & $52 \%$ \\
\hline \multirow{4}{*}{$\begin{array}{c}\mathrm{NH}_{3} \\
\left(\mu \mathrm{g} \mathrm{m}^{-3}\right)\end{array}$} & CB & $1.0 \pm 1.0 \mathrm{~b}$ & $0.3-2.6$ & $53 \%$ \\
\hline & TC & $0.7 \pm 0.1 \mathrm{c}$ & $0.1-1.7$ & $60 \%$ \\
\hline & CA & $2.5 \pm 0.2 \mathrm{a}$ & $0.6-5.3$ & $47 \%$ \\
\hline & LC & $0.7 \pm 0.1 \mathrm{c}$ & $0.1-1.7$ & $59 \%$ \\
\hline \multirow{4}{*}{$\begin{array}{c}\mathrm{HNO}_{3} \\
\left(\mu \mathrm{g} \mathrm{m}^{-3}\right)\end{array}$} & CB & $2.7 \pm 0.6$ & $0.0-14.5$ & $134 \%$ \\
\hline & TC & $1.5 \pm 0.2$ & $0.0-6.4$ & $73 \%$ \\
\hline & CA & $2.3 \pm 0.3$ & $0.3-9.7$ & $98 \%$ \\
\hline & $\mathbf{L C}$ & $3.3 \pm 0.7$ & $0.0-13.9$ & $134 \%$ \\
\hline \multirow{4}{*}{$\begin{array}{c}\mathrm{O}_{3} \\
\left(\mu \mathrm{g} \mathrm{m}^{-3}\right)\end{array}$} & CB & $57.0 \pm 2.4 \mathrm{c}$ & $10.8-86.1$ & $30 \%$ \\
\hline & TC & $69.1 \pm 2.9 b$ & $28.7-101.4$ & $30 \%$ \\
\hline & CA & $77.4 \pm 4.7 \mathrm{a}$ & $25.3-122.3$ & $32 \%$ \\
\hline & LC & $78.2 \pm 3.2 \mathrm{a}$ & $34.9-117.3$ & $29 \%$ \\
\hline \multirow{3}{*}{$\begin{array}{c}\mathbf{P M}_{10} \\
\left(\mu \mathrm{g} \mathrm{m}^{-3}\right)\end{array}$} & TC & $23.0 \pm 3.2 \mathrm{ab}$ & $5.2-61.0$ & $67 \%$ \\
\hline & CA & $26.9 \pm 2.6 \mathrm{a}$ & $6.8-49.2$ & $41 \%$ \\
\hline & $\mathbf{L C}$ & $18.0 \pm 1.5 \mathrm{~b}$ & $4.8-32.8$ & $41 \%$ \\
\hline \multirow{3}{*}{$\begin{array}{c}\mathrm{NO}_{3}^{-} \\
\left(\mu \mathrm{g} \mathrm{m}^{-3}\right)\end{array}$} & TC & $1.3 \pm 0.4 b$ & $0.1-8.1$ & $129 \%$ \\
\hline & $\mathbf{C A}$ & $2.2 \pm 1.5 \mathrm{a}$ & $0.5-8.8$ & $99 \%$ \\
\hline & $\mathbf{L C}$ & $1.1 \pm 0.2 b$ & $0.2-4.2$ & $80 \%$ \\
\hline \multirow{3}{*}{$\begin{array}{c}\mathrm{NH}_{4}^{+} \\
\left(\mu \mathrm{g} \mathrm{m}^{-3}\right)\end{array}$} & TC & $0.6 \pm 0.1$ & $0.2-2.7$ & $54 \%$ \\
\hline & CA & $0.9 \pm 0.2$ & $0.3-3.7$ & $97 \%$ \\
\hline & $\mathbf{L C}$ & $0.5 \pm 0.1$ & $0.0-1.6$ & $71 \%$ \\
\hline \multirow{3}{*}{$\begin{array}{c}\mathrm{SO}_{4}{ }^{2-} \\
\left(\mu \mathrm{g} \mathrm{m}^{-3}\right)\end{array}$} & TC & $1.2 \pm 0.2 b$ & $0.1-4.2$ & $70 \%$ \\
\hline & CA & $1.9 \pm 0.2 \mathrm{a}$ & $0.8-3.7$ & $48 \%$ \\
\hline & LC & $1.7 \pm 0.2 \mathrm{a}$ & $0.4-3.3$ & $52 \%$ \\
\hline
\end{tabular}

Mean: arithmetic mean \pm standard error. Min. - Max.: Minimum and maximum twoweek values. $\mathrm{CV}$ : coefficient of variation, representing the temporal variability. Different letters indicate significant differences $(p<0.05)$ between sites. The absence of letters indicates no significant differences. 
1 Table 3. Ozone exposure expressed as AOT40 for years 2011 and 2012, following 2 criteria from the Convention on Long-range Transboundary Air Pollution (CLRTAP) and 3 the Ambient Air Quality Directive 2008/50/EC.

\begin{tabular}{ccccc}
\hline \multicolumn{3}{c}{ AOT40 (ppm h) } \\
\hline \multirow{2}{*}{ SITE } & \multicolumn{2}{c}{$\begin{array}{c}\text { CLRTAP } \\
\text { (Jan-Dec) }\end{array}$} & \multicolumn{2}{c}{$\begin{array}{c}\text { Directive 2008/50/EC } \\
\text { (May-July) }\end{array}$} \\
& $\mathbf{2 0 1 1}$ & $\mathbf{2 0 1 2}$ & $\mathbf{2 0 1 1}$ & $\mathbf{2 0 1 2}$ \\
\hline CB & 8.2 & 18.8 & 3.7 & 9.4 \\
TC & 31.8 & 49.6 & 17.4 & 28.3 \\
CA & 32.6 & 32.3 & 15.5 & 16.5 \\
LC & 27.3 & 34.9 & 12.5 & 18.3 \\
\hline
\end{tabular}

4

5

6

7

8

9

10 
1 FIGURE CAPTIONS

2 Fig. 1 Distribution of Quercus ilex habitats in Spain, and location of the study sites. LC: La 3 Castanya (Barcelona); CB: Can Balasc (Barcelona); CA: Carrascal (Navarra); TC: Tres Cantos 4 (Madrid).

5 Fig. 2 Seasonal mean concentration of atmospheric pollutants in the open-field $(\mathrm{O})$ plots of the 6 four study sites and standard error of the mean. Different letters indicate significant differences 7 amongseasons.

8 Fig. 3 Seasonal mean concentrations of aerosols and standard errors, and ratios of particulate to 9 gaseous pollutants in the three aerosol monitoring sites. A) $\mathrm{PM}_{10}$ concentration; $\left.\mathrm{B}\right) \mathrm{PM}_{10}$ 10 concentration for measurements during Saharan dust events compared with the rest of the 11 samples; C) particulate nitrate concentrations; D) particulate ammonium concentrations; E) 12 concentrations ratios of nitric acid and particulate nitrate, expressed as percentage of the sum of 13 both compounds; F) concentrations ratios of ammonia and particulate ammonium, expressed as 14 percentage of the sum of both compounds. Different letters indicate significant differences 15 between seasons. One outlier value (CA, spring) was removed from the graphs C-F.

16 Fig. 4 Mean concentration of pollutants in O plots (open field) and F plots (below canopy), and 17 standard error of the mean. Significance of the Wilcoxon matched pairs test: *: p < 0.05; **: $p<$ 18 $0.01 ; * * * \mathrm{p}<0.001$. 


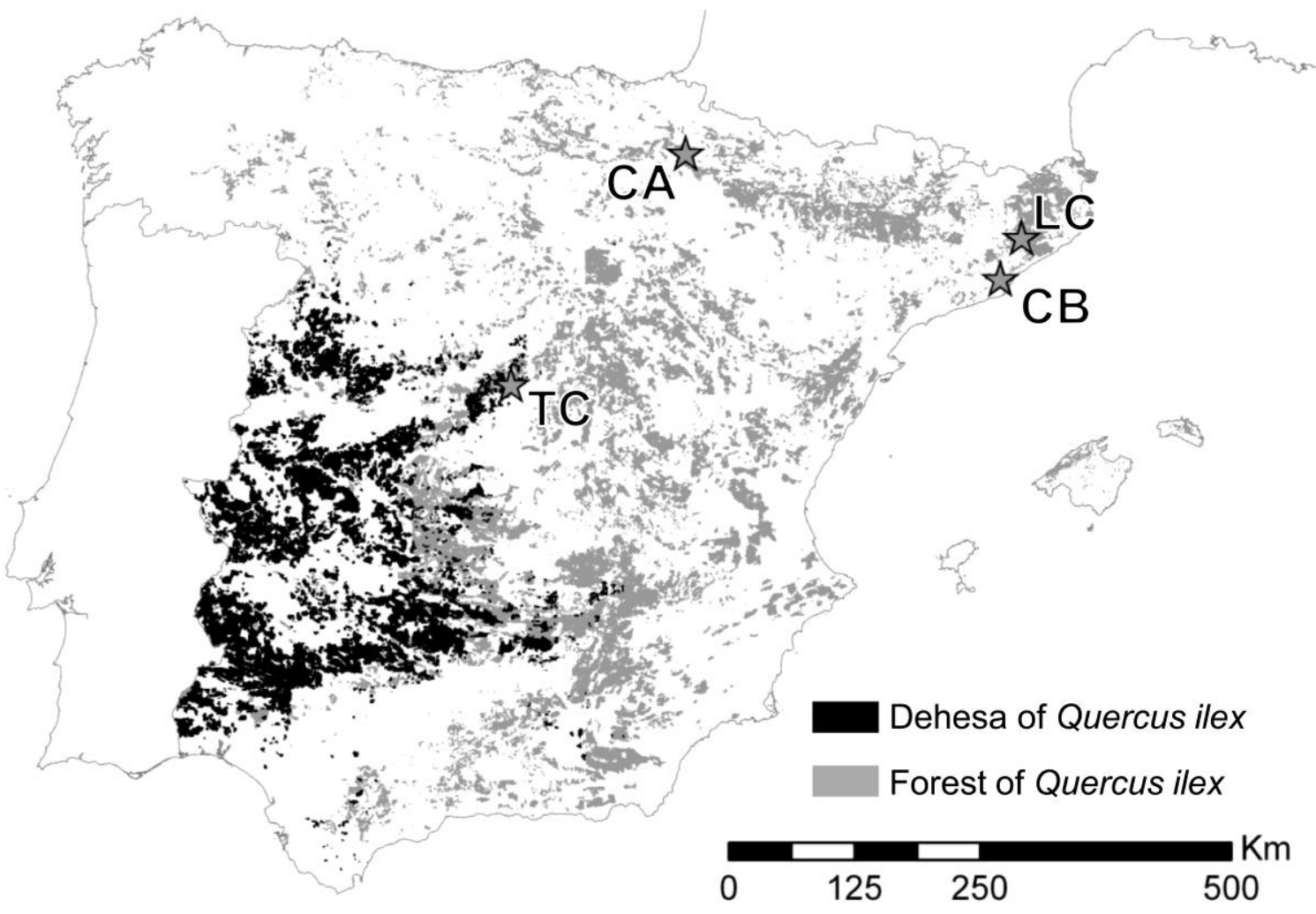

9 
$1 \quad$ Fig. 2

2

3

4

5

6

7
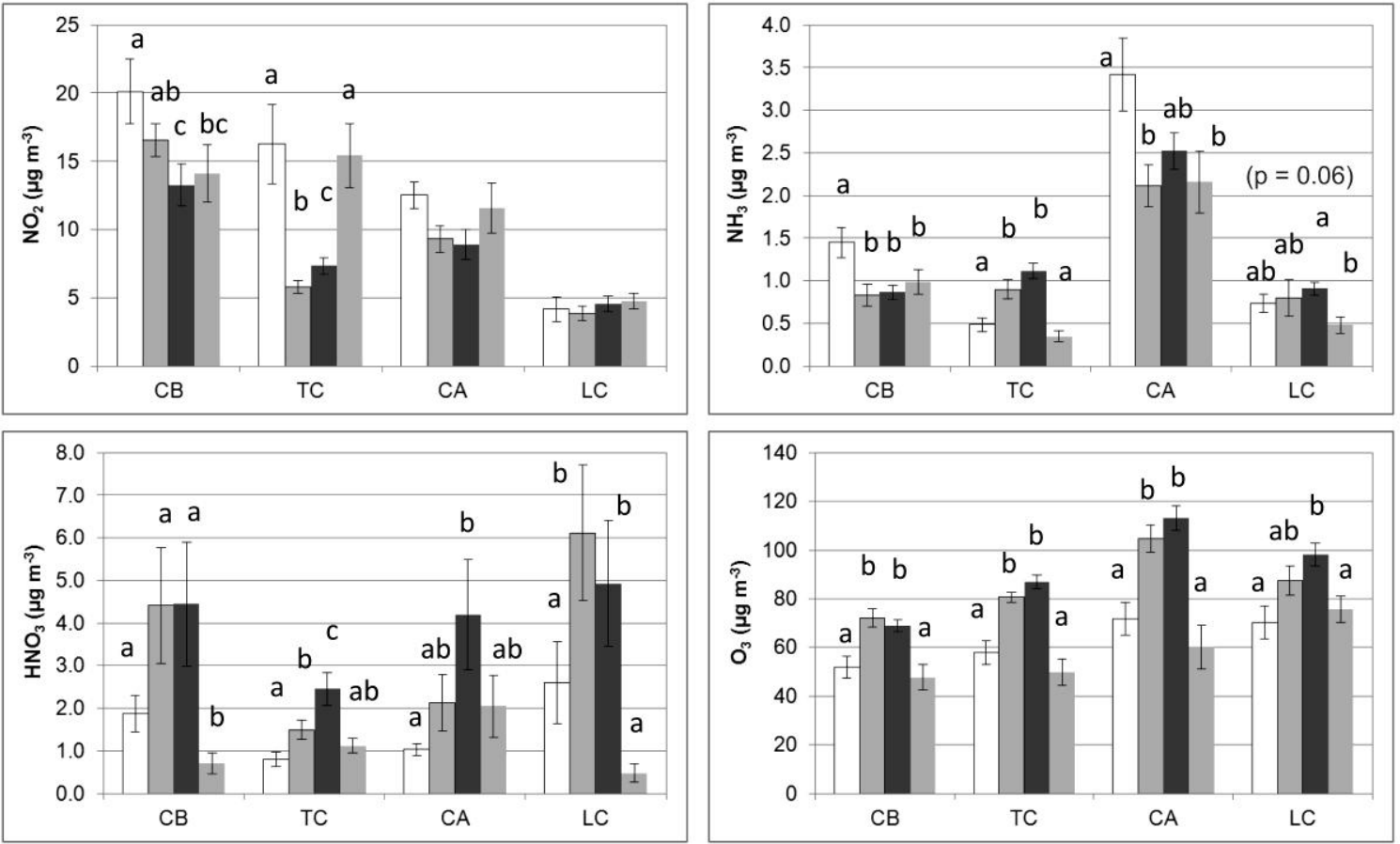

8

$\square$ WINTER $\square$ SPRING $\backsim$ SUMMER $\approx$ AUTUMN

9 
Fig. 3

2
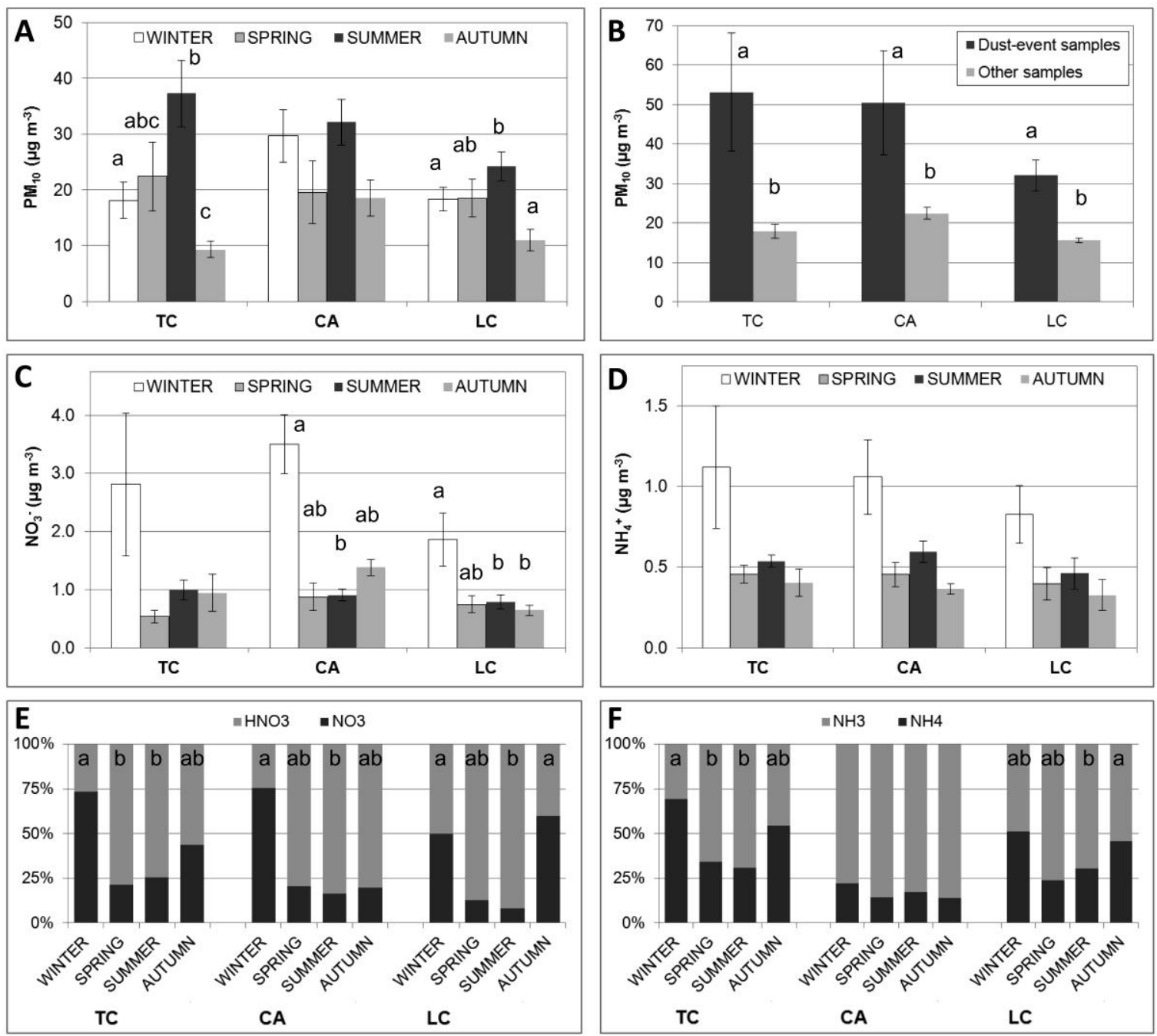

6 
1 Fig. 4

2

3

4

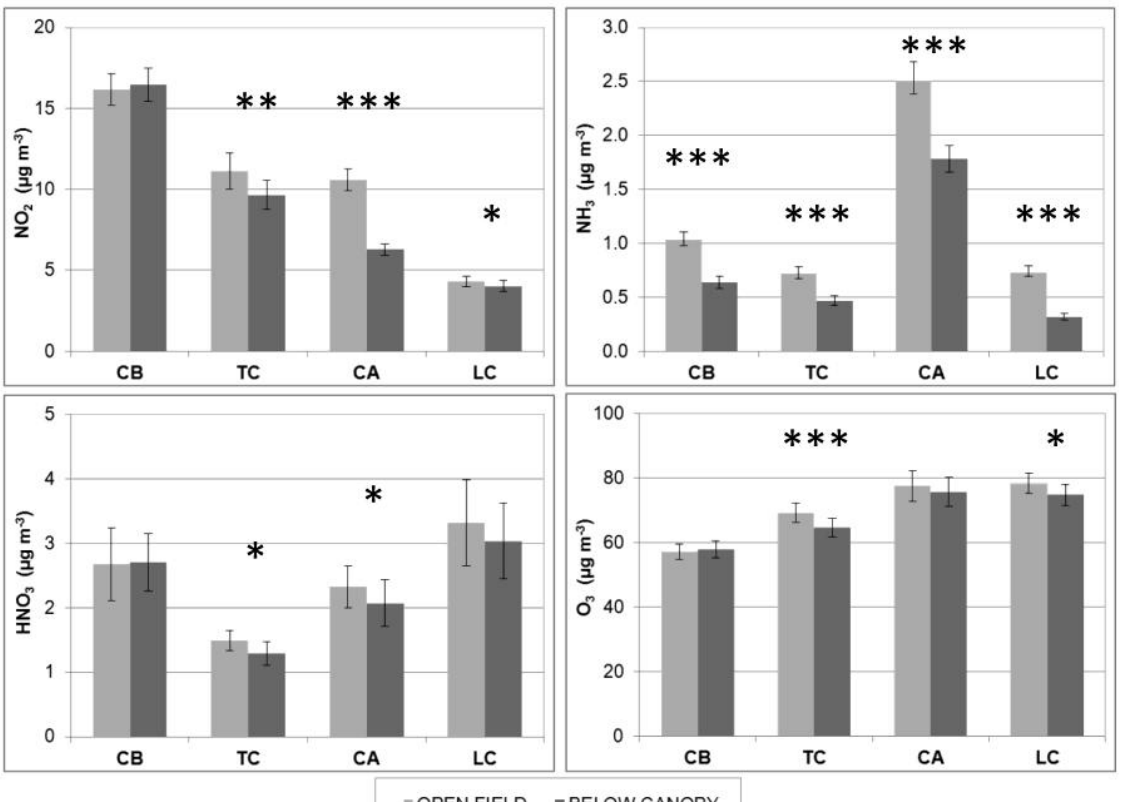

5

=OPEN FIELD =BELOW CANOPY 